\title{
The Forms and the Methods of State Influence on the Innovation Climate Factors (On The Example of the Russian Federation and the Tatarstan Republic)
}

\author{
Safiullina A.M. \\ Ivanov M.E. \\ Ramazanov A.V. \\ Kazan (Volga region) Federal University, 18, Kremlyovskaya Street, Kazan, \\ Repablic of Tatarstan, Russian Federation, 420008
}

\section{Doi:10.5901/mjss.2014.v5n18p211}

Abstract

The article describes forms and methods of government influence on the innovation climate factors (on the example of the Russian Federation and the Tatarstan Republic. The role of regional authorities is extremely important and it includes settings of goals and principles which are responsible for effective management of innovation development factors in the region. The government's role in the innovation economy development is to create the necessary infrastructure and legal environment, resolving issues using the results of intellectual activity, the creation of conditions for the effective application of science and technology for the production of a commercial product by Russian enterprises.

Keywords: innovations, innovation climate, methods, factors, innovation policy.

\section{Introduction}

Basics of the Russian innovation policy were laid in the 1990's and set out in Federal law "On Science and State Scientific and Technological Policy" in 1996. During this period the State took active measures to support science under crisis conditions and at the same time to establish new institutional environment, new mechanisms and institutions for science and innovative activities.

In the 2000's experts began to prepare the conceptual documents, called to specify the strategic, long-term research and innovation policy and to incorporate it into other economic initiatives of the State. During this period, problems of formation of the national innovation system and transition to the innovation economy, embodied in a number of government documents were formulated. This section considers the main objectives and tasks, set forth in documents of this period, analyzes changes in the structure of public administration and incentives for innovation development.

The role of regional authorities is in goal, objectives and principles of the formation of protruding direct "frame" and ensuring effective management of factors of innovation development in the region. The result of the data management system elements is the formation of the strategy and its implementation [1].

\section{Theory}

In accordance with Federal law "On Science and State Scientific and Technological Policy" (redrafted in 2006), main objectives of the state scientific and technological policy as a main component of innovation policy are development, rational distribution and efficient use of technological capabilities, enhancement of the contribution of science and technology in the development of the country's economy, the implementation of primary social tasks, provision of progressive structural changes for the field of material production, enhancement of its efficiency and competitive advantage of production, improvement of environmental conditions and protection of information resources of the state, strengthening of the state's defenses and security of a person, society and state, integration of science and education [2, 7].

The government scientific and technological policy is carried out on the basis of the following major principles;

- Acknowledgment of science as a socially significant branch, which determines a level of development of productive forces of the state. :

- Publicity and use of various forms of public debates in selection of priority directions of science and technology 
development and examination proceedings of research and technology programs and projects, which implementation is based on competition.

- Guarantee of priority development of basic scientific research.

- Integration of science and education in R\&D on the basis of various forms of participation of teaching staff, postgraduates and students of higher professional education institutions through establishment of studyresearch complexes, laboratories, based on higher professional education institutions, platforms on the basis of scientific organizations of government academies of sciences, as well as research organizations of federal executive authority.

- Support for competition and entrepreneurial business in science and technology.

- Concentration of resources in priority areas of science and technology.

- Promotion of scientific, technological and innovation activity through a system of economic and other benefits.

- Development of scientific, technical and innovation activity through creation of public research centers and other structures [3].

\section{Results}

The state's role in the development of innovative economy is to create the necessary infrastructure and legal environment, resolving issues using the results of intellectual activity, the creation of conditions for the effective application of science and technology for the production of a commercial product by Russian enterprises.

Innovation policy in different regions of the Russian Federation has its own characteristic. However the uniform remains the basic tools for its implementation: the legal framework, targeted programmes, concepts, etc. One can distinguish internal and external dimensions of the innovation potential of the region. Among the internal there are: financial and credit system, economic structure, the research base, the system of formation and development of personnel potential of the region. The external components include: integration cooperation with other regions, socioeconomic competitiveness of the region, the possibility of entering the global level.

As for the Republic of Tatarstan, there are different types of established infrastructure and economic and scientific activities designed to ensure the full functioning and dynamic development of innovative processes.

Among institutional agents playing on the field of innovation economy RT one should allocate some "influence groups", which differ in their objectives, occupation, origin and personnel.

One should consider the following elements of the innovation "ecosystem": industrial parks, business incubators, venture funds, professional associations and academic institutions, institutions of secondary and higher education, as well as governments $[4,5]$.

Below it is summarized the core institutional agents of high-tech industry of Tatarstan.

a) administrative and economic agents

Modern Tatarstan is strictly orderly society where competitive advantage is the key contact embeddedness into the regional administrative system, which tied the main financial flows. Among the most important administrative agents of the innovation economy should be called the Ministry of Economy of the RT, the Committee to support small and medium-sized businesses, Investment Promotion Agency and the Investment and Venture Fund of the Republic of Tatarstan.

b) industrial parks, business incubators, and other development institutions

The second group of agents of the innovation economy of Tatarstan is formed by technology parks, business incubators, special economic zones and industrial parks. Innovative development tools designed to change the structure of the regional economy, stimulate, not tied to raw materials, and to produce goods with high added value, and sought not only in domestic, national, or Russian, but also in international markets.

Work of special economic zones, industrial parks, science cities is designed to serve the new spread advanced culture production of effective models of integration of education, science, the real economy and business. Over the past 10 years in Tatarstan was established extensive network of institutions for innovative development. Among them may be mentioned SEZ "Alabuga" technopolis "Himgrad " Technopark "Idea », IT- park, technopark " Kama " industrial parks "Master" and "Kama field" , etc.

c) contests, free programmes for the development of innovations

A large role in creating an attractive investment image of the country as well as in promotion at the regional level "knowledge economy" play all kinds of communication and presentation activities.

d) associations that promote the growth of technological entrepreneurship.

In addition to development institutions, contests, forums, as well as administrative agents in the innovation 
ecosystem of Tatarstan public have a certain value and professional associations, which are aimed at the development of small and medium businesses in the country.

It seems that under the administrative control of the integrated system and clan model of building relationships (traditional for the region), the role of NGO involvement and public associations in the development of innovative economy is not so big.

However it is impossible completely exclude the "public institutions" into the local innovation ecosystem production. Tatarstan among NGOs and professional associations would like to mention the Chamber of Commerce of the Republic of Tatarstan, regional associations of small and medium-sized businesses, as well as a youth club "Navigator".

e) investors innovation economy of RT

No business is possible without the involvement of investments. The institutions that invest to high-tech cluster of Tatarstan's economy can be analytically divided into three groups: regional investors, domestic investors and international investors.

Basis for the formation of the Republican policy in the sphere of innovation is the Law of the Republic of Tatarstan " On innovation activity in the Republic of Tatarstan", which defines the forms and methods of state regulation of innovative processes and legal framework of the state support of business entities engaged in research and development activities .

In order to support the development and innovation sector in the Republic of Tatarstan Republic of Tatarstan Act of November 28, 2003 N 49 -LRT " On Property Tax organizations " established a preferential rate of 0.1 per cent property tax technology parks (industrial parks), innovation technology centres were created in accordance with the decisions of the Government of the Russian Federation or the Cabinet of Ministers of the Republic of Tatarstan to implement innovative projects.

To research, design institutions (organizations), pilot and experimental enterprises regardless of their organizational and legal forms of ownership, in the total amount of work that research, developmental and experimental work is no less than 70 percent of the total amount income of the organization received in the tax (reporting) period, established the rate of property tax at a rate of 1.1 percent.

In accordance with the Council of Municipalities of the Republic of Tatarstan subjects of innovative activity is partially or fully exempt from tax on the ground.

As already mentioned, the organization resident SEZ "Alabuga" is exempted from property tax from the moment of property registration and land tax from the moment of the ownership of land, as well as completely exempt from vehicle tax to be credited to the budget of the republic.

Law of the Republic of Tatarstan on February 10, 2006 N 5 -LRT " On establishing the tax rate on income tax for organizations resident of a special economic zone of industrial type established in the territory of the Republic of Tatarstan Yelabuga district " provides for the application of the zero rate of income tax in terms of payable to the budget of the Republic, during the first five years of the taxable profit for the next five years, the tax rate is 5 percent, and after 10 years will act rate of 13.5 percent. This law creates an additional incentive for investors interested in investment projects in the Russian Federation. [6]

Effective instrument for financing innovation projects is launched in 2010 to provide targeted subsidies programme to small and medium-sized enterprises of the Republic of Tatarstan for the development of innovation and technological modernization of production:

- Subsidies for beginners small innovative companies (one year from the date of registration jur. persons) are available in the amount of 500 thousand rubles, but not more than 85 percent of the total cost of the business project;

- Subsidies applicable to small innovative companies ( more than one year from the date of registration of the legal entity) in the amount of 5 million but not more than 75 percent of the total cost of the business project ;

- Subsidies to entrepreneurs of the Republic of Tatarstan for the partial financing of the costs associated with the payment of fees under a finance lease (leasing) equipment;

- Subsidies for the purpose of providing financial support to entrepreneurs of the Republic of Tatarstan, producing and (or) selling goods ( works, services) for export .

Acquisition of new projects in innovative activities carried out by close cooperation with higher education institutions of the Republic of Tatarstan, the research institutes of the Russian Academy of Sciences and the interaction with the Academy of Sciences of the Republic of Tatarstan. Support is needed annually in an average of about 900 innovative projects, participating in the national competition " 50 best innovative ideas for the Republic of Tatarstan ", which aims to stimulate innovation scientists, inventors, graduate students, and students and creates conditions for the introduction into the economy of the Republic of Tatarstan new promising technologies, the development of high-tech industries to increase competitiveness of products of the Republic of Tatarstan. 
Legal basis of the use of different tax instruments to support investment activities in the Republic of Tatarstan enshrined in the laws of the Republic of Tatarstan:

- November 25, 1998 N 1872 "On investment activity in the Republic of Tatarstan"; [8] - August 2, 2008 N 53 -LRT "On establishing the tax rate on corporate income tax for certain categories of taxpayers "; $; 9,11]$

- October 10, 2011 N 68 -LRT "On investment tax credit in the Republic of Tatarstan". [10]

- Investment activity entities implementing investment projects on the territory of the Republic of Tatarstan, granted privileges:

- Income tax on newly acquired property for the project in the amount of 2.1 percent (tax rate reduction from 2.2 to 0.1 percent);

- Tax profit of 4.5 per cent in part transferred to the budget of the Republic of Tatarstan (tax rate reduction from 18 to 13.5 percent).

- Currently republican executive bodies are working on the implementation in practice of the use of additional tax incentive - the investment tax credit (hereinafter - ITC) by granting a delay tax payments with subsequent gradual payment of the loan and accrued interest on the amount determined on the basis of investments made and volumes organization paid taxes.

Norm on the availability of this preference, fixed in the Tax Code of the Russian Federation, has been developed in the Law of the Republic of Tatarstan "On investment tax credit in the Republic of Tatarstan" [10].

According to the aforesaid law investment tax credit may be granted:

- Tax profits tax rate established for enrollment in the budget of the Republic of Tatarstan;

- Regional tax ( business property tax, transport tax ).

This form of support can be applied to organizations engaged as research or experimental development, implementation or innovative activities, including the creation of new or improvement of existing technologies, the creation of new types of materials or supplies.

\section{Conclusions}

In general, there is an impressive amount of Tatarstan institutions innovation. Creating eight industrial parks and planning to develop two more Tatarstan with a population of only 3.8 million people has more industrial parks than the entire Kazakhstan, industrial parks and more per capita than the United Kingdom, which is one of the countries, the birthplace of industrial parks. The country has created favorable conditions for new high-tech industries. According to the territorial body of the Federal State Statistics Service of the Republic of Tatarstan, the number of organizations which are involved into the innovation and technological innovation, as well as the costs of technological innovation in the Republic of Tatarstan in 2011 took 1st place among the regions of the Volga Federal District.

\section{References}

Background report to the OECD country review of the Russian innovation policy 'National innovation system and state innovation policy of the Russian Federation", Moscow,2009, pp68-88.

Boschma, R.(2005), "Proximity and Innovation: a critical assessment." Regional studies 39(1): pp.61-74

Braczyk, H-J., Cooke, P., \& Heidenrech, M. (Eds),(1998),Regional Innovation Systems. London/Bristol PA: University College London Press.

Carlsson, B .Internationalization of Innovation Systems: a survey of the literature. Research policy, (2006),35(1), pp 56-67

Shaidullin R.N., Ulesov D.V., Shigabieva A.M. and Safiullin L.N. Innovative Infrastructure in Post-Industrial Societyl/ World Applied Sciences Journal, 27(13), 2013, pp. 180-183.

Ulesov D.V., Murtazina G., Safiullin L.N. and Saipullaev U.A. Special Aspects of Development of Business in the Knowledge-Based Economy //World Applied Sciences Journal, 27(13), 2013, pp. 189-192.

Jensen, M.B., B. Johnson, et al. (2007). "Forms of knowledge and modes of innovation". Research policy 36(5): pp.680-693

Hadiullina, G.N., Nugumanova, L.F., Bagautdinova, N.G., Averiyanov, B.A. Transformation of the households functions in the modern Russian economy // World Applied Sciences Journal, 27(13), 2013, 111-115.

Gainova R.A., Shaidullin R.N., Safiullin L.N. and Maratkanova E.M. Infrastructural Component in Maintenance of Competitiveness of Region// World Applied Sciences Journal, 27(13), 2013, pp. 97-101.

Bagautdinova, N.G., Novenkova, A.Z., Sarkin, A.V. Quality management system formulation and implementation as a factor of enhancement of the university role in the local development // World Applied Sciences Journal, 27(13), 2013, 38-42.

Safiullin M.R., Samigullin I.G. and Safiullin L.N. Model of Management of Competitiveness of a Machine-building Complex// World Applied Sciences Journal, 27(13), 2013, pp. 212-216. 